\title{
Promise and Practice of the Principle of Equal Access to Information in the Danish Local Administration
}

\author{
Pernille Boye Koch \\ Roskilde University, Department of Social Sciences and Business, Denmark \\ pkoch@ruc.dk \\ https://orcid.org/0000-0001-8067-5558
}

Received: 6. 3. 2019

Accepted: 21. 8. 2019

\section{ABSTRACT}

This article presents an empirical based study of the implementation and effectiveness of freedom of information acts (FOIAs) in Danish municipalities. Even though the Nordic Countries are known for transparent public institutions, empirically based studies of access to information are rare. With the help of 33 students of public administration, 146 simple requests were sent covering $74.5 \%$ of all Danish municipalities. The primary purpose of the field experiment was to test the legal principle of identity-neutrality and equal treatment, as the profile of the applicants was varied: the first set of requesters represented "simple" identities, while the second set of requesters represented "qualified" identities. Besides, the requesters asked for two different types of information, one more controversial to reveal than the other. Hence, the study looked into variations in casework time, likelihood of rejection, communication form, etc. The results of the study showed that, in general, the municipalities handled the requests for access to information without difficulties and within the set deadlines, and no differential treatment of applicants based on their status and qualifications could be observed. In addition, the data indicates a significantly higher processing time in the requests for potentially controversial information. The study opened up grounds for future field experiments on FOIA(s). In the final part of the article, the general benefits of student involvement in research processes are discussed.

Keywords: transparency, access to information, equal access, FOIA - Freedom of Information Act, implementation, municipalities, Denmark

$J E L: K 23$

\section{Introduction}

Access to information as a universal right, regardless of personal status, is an important element of most democratic states. Denmark has, like the other Nordic countries, a quite long and well-established history of transparency 
in public administration and a tradition of involving citizens in political and administrative processes (Knudsen, 2003; Jørgensen, 2014). However, during recent years, the principle of access to Information in Denmark has been under pressure, as a new Access to Information Act has been accomplished, implying more secrecy concerning central political decisions (Koch, Gottrup and Gøtze, 2018; Koch and Gottrup, 2019). In addition to this legal development, these years the Danish public sector experiences cutbacks and especially the municipalities are having difficulties due to increasing expenses and decreasing income. This financial pressure could possibly influence the willingness to prioritize access to information requests. On this background, it seems relevant to examine how the praised principles of transparency in public administration are implemented in practice and how the transparency culture manifests itself in the daily life of the local authorities.

An important supplementary element of this study, however, is the involvement of students in the research process. Hence, public administration students following a course in administrative law were engaged in designing and carrying out the field experiment. The course in administrative law is a traditional theoretical course aiming to teach students about the formal legal framework of public institutions. Even though practical work with fictitious cases is already included in the lectures, the engagement of the students in seeking access to information in actual municipalities in real life could reinforce their understanding of the legal principles in practice.

The study represents findings of a field experiment involving a total amount of 146 requests covering 73 out of 98 Danish municipalities ( 74.5 pct. of all municipalities). The main purpose of the field experiment is to examine the administration of simple requests for access to information and to test the legal principle of identity neutrality and equal treatment.

Even though access to information regulation is seen as a cornerstone in Danish administrative law, implementation studies are a rare occurrence. Whereas the Danish formal legal framework is rather well described in the literature, the empirical perspective has not attracted much attention. However, in the wake of the recent debates on the new Access to information Act, some statistics and reports have been collected from the state administration showing e.g. number of cases, rates for approval and rejection, casework time etc. (Justitsministeriet, 2017). Nevertheless, research based field experiments are in short supply.

Thus, the aim of the study is to answer the following research questions: 1) How are Danish municipalities handling simple requests for access to information in terms of casework time? 2) Are requesters treated systematically better, if they appear to be more qualified and state a reason for applying for access? 3) Are requests for sensitive political information handled more slowly than requests for non-controversial information? 


\section{Transparency and field experiments}

Transparency and Access to Information are closely linked, as access to information can be seen as a way of institutionalizing transparency in rules and procedures (Berliner, 2014). In the political science literature, the discussions of transparency has primarily been focusing on transparency as an instrument for securing good governance and a well-functioning public sector (Hood \& Heald, 2006; Berliner, 2014). Consequently, many studies concern for instance the relationship to public sector corruption (Escaleres et. al., 2010), trust in Government (Grimmelikhuijsen, 2013) or empowering (Meijer, 2012). In law and legal studies, the literature typically presents differing justifications for transparency, for instance effective administration, democratic accountability or human rights (Vaughn, 2011). Hence, the legal discussions draw on several legal disciplines such as constitutional law, administrative law and human rights law (Dragos et. al., 2019).

Although Scandinavia is considered a front-runner of transparency legislation, there is not a strong tradition of empirical based studies of access to information in the public administration as only few and limited field experiments has been conducted. Moving the spotlight outside Scandinavia yields better results. Thus, interesting field experiments have taken place in Countries like Brazil (Michener and Rodrigues, 2015), the United States (Lewis and Woods, 2012), New Zealand (Price, 2006), Mexico (Lagunes and Pocasangre, 2017) and England (Worthy, John and Vannoni, 2017). However, focus of these studies has varied. Some have concentrated on the effects of transparency on the organization by testing e.g. the link between access to information and corruption deterrence, while others have been looking into the effectiveness and appliance of access to information legislation. ${ }^{1}$ There are even field experiments focusing more specifically on equal access and the identity of the applicant (Lagunes, 2006, 2017; Michener and Rodrigues, 2015) and/or the wording of the application in order to identify potential bias (Cuillier, 2010).

Lastly, attention can be drawn to the prevalence of a few studies examining the impact of the political sensitiveness of the requested information on the responsiveness of the authorities (Lewis and Woods, 2012; Price, 2006). The conclusions from these last-mentioned studies seem to be that there is a significant variety in response rates and time depending on the extent of sensitiveness and political accountability.

As already mentioned, Scandinavian studies have been scarce. In Denmark, a few experiments have been accomplished by the Danish Journalists Association (Journalisten, 2009) and by one of the nationwide newspapers (Information, 2015) in order to test the effectiveness of access to information rights. Mostly with poor results consisting of delayed answers. Danish academic studies is as far as is known not accomplished apart from a few student projects (as referred in Tim Knudsen, 2003).

1 For a literature review, see Worthy, John \& Vannoni (2017), p. 490. 
An interesting field experiment has been conducted in Finland, but due to lack of publication of results etc. in English, we have only limited knowledge of the details of the study. However, it appears from a Google-translation of a Finnish newspaper-article that it concerns an experiment from 2010 accomplished by four Political Science students under the guidance of Professor Matti Wiberg from University of Turku (Helsingin Sanomat, 2010). Under fictitious names, the students send out 230 inquiries to different State authorities asking for access to senior executive salaries. The result of the study - though scarcely described in the newspaper article - was discouraging. From the majority of the authorities, the answers were either delayed or completely missing, and the attitude and language of the administration was often arrogant and aggressive. According to the newspaper article, the applicants were often asked for the purpose of the request and sometimes even asked to call or attend the administration in person, even though this was not according to the law.

\section{The Danish legal framework}

\subsection{General principles}

Denmark adopted its first law on access to information in 1970, and although the right to access to information on administrative authority does not have a constitutional basis, the FOIA (Access to Public Administration Files Act, 2013) is considered as a cornerstone in Danish administrative law (For a general introduction: Andersen, 2013; Revsbech, 2014, pp. 242-267; Bønsing, 2013, pp. 212-240 and Ahsan, 2014). The Danish FOIA has been revised on a number on occasions (For an overview, see Ministry of Justice, 2009), but the basic principles remained. In this context, it is relevant to mention the reform in 1985, which included the municipalities under the scope of the act. Thus, the Danish FOIA covers all material in the public sector, i.e. in the state administration as well as in the regional administrations and municipalities.

The overall framework of the FOIA is based on openness, and this is its explicit point of departure. Yet although citizens' right to access to documents is the main aim of the Act, almost half of the sections in the Act contain exceptions to this. The catalogue of exceptions can be broadly divided into three main categories, namely: 1) exempted cases pertaining to specific subject matter such as criminal cases and employment cases; 2) exempted documents such as internal documents; and 3) exempted pieces of information such as personal data. All rules on documents excluded from access to information are absolute in the sense that the documents can and will be excluded from public disclosure if the document is covered by one of the three exceptions. No public interest-test is integrated in the Access to Information Act. In other words, the authorities do not have to balance the importance of the requested information against the importance of confidentiality. However, the authorities have a duty to consider extending their openness on their own initiative, and in that connection a potential public interest can come into play.

One of the newcomers in the FOIA from 2013 was an explicit preamble clarifying the aim of the access to information act. Thus, according to the new sec- 
tion 1, the purpose of the act is multiple: First, access to information is crucial for the existence of freedom of expression. Second, access to information in public authorities can advance the involvement and participation of citizens in the decision-making processes. Third, FOIA is an important precondition for holding the authorities responsible for their behavior. Fourth, access to information is crucial for the media in their role as informing the public. Last, but not least, transparency is believed to create public trust in the public administration.

\subsection{The requirement to be applicant blind}

In Denmark, as well as in many other countries (Dragos, 2019), there is neither a nationality condition nor an age requirement, when applying for access to information in the public administration. Moreover, an important feature of Danish transparency legislation is the no-requirement for the applicant to present or justify an interest, a legal interest, in the relevant documents or piece of information. Consequently, the public authorities are not permitted to ask for the identity nor the motives of the applicants.

Even though the requirement to be applicant blind is fundamental in Danish Access to Information regulation, it is also subject to modification. Recently, a new rule has been introduced, implying certain benefits for journalists employed or affiliated mass media, in the sense that a new possibility of denying access to information is not in the same extent applicable on requests from journalists. The new rule permits the public authorities to refrain for accommodating a request for file access, even though nothing substantial in the documents speaks against it, namely if the case handling will necessitate a disproportionate use of resources. In the preparatory work, however, it is emphasized that the exception should not be used if the considerable resources are needed because of inappropriate records management, or if the person seeking access has a special interest in the information/documents. In that connection, it is mentioned that mass media and researchers from research institutes are considered having a special interest.

Thus, the requirement to be applicant blind is deviated in situations with comprehensive requests of access to information covering a wide range of documents and/or including comprehensive filtering out confidential information. Moreover, it is highly probable that the resource-criteria has generated more attention than previously to the identity of the applicant and the motives behind the request for access to information.

\subsection{Time limits}

The Danish Freedom of Information Act implies quite tight limits, as the current act contains shorter deadlines than the previous regulation. Thus, decisions must be made with no delay as to individual applications for access to documents. There must be a specific reason for a delay - such as the complexity of the case - of more than 7 working days. There are no time limits in the law if the public authority states that the case is complex and cannot meet the 
seven-day-rule but according to guidelines from the Ministry of Justice and from the Ombudsman, even the most comprehensive application should be dealt with within 40 working days. If the application is not dealt with within the stipulated time limits, the applicant should be notified of this and given an indication as to when the decision will be made.

The practical usage of the various provisions on time limits is described in the 2017-report from the Ministry of Justice (Justitsministeriet, 2017), and it is interesting that the stipulated deadlines have in practice proved highly difficult to comply with. Most ministerial departments cannot process applications on access to document within 7 days and the main rule in practice is something like 10 to 20 days according to the data collected by the Ministry of Justice in the 2017-report. As to local public administration such as Danish municipalities no exact data has been collected but the municipalities have expressed strong concerns in the 2017-report on the tight time limits and they are considered unrealistic.

\section{Methods}

As already mentioned, a central aim of the current study is to explore whether the fine ideals behind the principles of FOIA are actually observed in practice, when civil servants are handling request for information in the daily life of the public administration. The original intention was to cover all Danish municipalities, but due to practical circumstances in involving students in collecting data, we ended up in covering 73 municipalities (74.5\% of the total number of municipalities) by sending a total amount of 146 requests, 2 per each municipality.

Two separate field experiments were accomplished with the help of 33 public administration students. In order to test the legal principles of identity-neutrality and equal treatment the 33 public administration students used their personal e-mail addresses to apply for access to two identical pieces of information in the given municipalities. However, the profile of the applicant was varied, so that the first set of requesters ( $50 \%$ of the applicants) represented "simple" identities (the name of the requester) while the second set of requesters represented "qualified" identities as their institutional affiliation (university students of public administration) and their professional interest in the subject was stated in the application.

The A-requesters were asked - as far as possible - to use an email address, where their status as university students did not appear, e.g. if they had a personal account. Additionally, they were provided with a specific text designed by me for the specific purpose. Thus, the A-requesters made use of identical email-texts when asking for access to information; only the name of the specific municipality (and the name of the nursing home to which the requested information relates) was filled out by the relevant student before sending the request. The wording of the email text was formulated by the teacher in a rather informal way with the purpose of appearing realistic; as something 
a standard citizen with no special qualifications would write. Following that line, the request did not include references to articles in the FOIA, neither did the mail use technical terms. Moreover, no specific reasons or motives for the request was stated.

As opposed to this, the B-requesters were urged to use their university-email and state explicitly their status as students of public administration at Roskilde University. These students too were provided with identical texts designed by the teacher in order to ensure comparability in the study. In this case, however, the wording of the e-mail was designed differently. The text was not written in officialese, but it included references to specific legal provisions and therefore appeared qualified as being sent from someone with specific knowledge of rights and duties in public administration. Moreover, a specific purpose of the request was stated in the mail, namely that the information was needed for the purpose of a specific study project on the Bachelor Program in Politics and Administration at Roskilde University.

All the participating students (the requesters) were asked to send two different requests to each municipality. The first application asked for access to a municipal inspection report on a specific nursing home from 2016; a randomly chosen nursing home, which each student has found by searching the Internet for nursing homes in the relevant municipality. According to the law, the authorities are obliged to conduct inspections to all nursing homes once a year. Thus, a high degree of certainty that these reports actually existed, which was important for the research design.

The second application asked for insight in specific information (name, wage level and performance contract) about the top manager of the municipal administration ("kommunaldirektøren"). According to the Danish FOIA, you have a right to access in key information on certain public employees personal matters. Thus, Section 21 explicitly states, that even though you cannot gain access to cases on recruitment, advancement and disciplinary actions concerning personnel in the public administration, there is a central exception gaining access to information about the employees name, position, educational background, working tasks, salary etc. When it comes to top leaders of the administration, you even have access to potential performance contracts with their superior. As in the previous case, every single municipality undoubtedly is in the possession of this information on the salary of the top manager.

The two different requests for insight were not sent simultaneously. The students were asked to send the request for access to the inspection report first, and the other request on the wage level of the highest-ranking civil servant 8-10 days later. The purpose of this time interval was to reduce the risk of giving the impression that these requests were just a part of an experiment, and not genuine requests. The students were instructed in mailing a reminder to the administration, if they did not have an answer within 10 days.

In light of the aforementioned financial difficulties of many Danish municipalities, the ethical aspects were carefully considered of sending a large amount 
of requests for access to information for the sole purpose of testing the principle of equal access and the general implementation of transparency regulation. On that background, we carefully chose to ask for insight in material and information we have reason to believe was easily identified and which did not imply much workload for the authority. This was also important due to the earlier mentioned resource-rule, which allowed the municipality to reject requests too time-consuming.

\section{Results}

As already mentioned, the first research question was how Danish municipalities are handling simple requests for access to information in terms of casework time. In that connection, a crucial question is what the study actually tests and how the research design substantiates to test it. First, it is important to emphasize that the two requests did not involve difficult legal assessments, neither disputable rulings. The law is quite clear: According to the Danish FOIA, everyone has the right to obtain access to material such as a municipal inspection report concerning a nursing home, while such a report does not contain personal or confidential information, which can justify an exception to the principle of openness. The same is true of the other request: According to the Danish FOIA, section 22, everyone has the right to obtain access to the wage level and other central terms of employment of the top leader of the administration. From a legal point of view, there is no room for opinion. Thus, the purpose of the study was not to test varieties in legal discretion.

Hence, the primary measurement criterion is casework time based on the assumption, that quick and effective handling of the request of access to information is of utmost importance. Besides, there is reason to believe that requests that are inconvenient for the authorities probably will result in longer case work time and delayed answers than in the case of non-controversial requests. In addition to the focus on casework time, the study aims to identify other relevant differences in the way the municipalities handle access to information requests. More specifically, this could be the overall approach of the authority, the communication form, the attitude etc.

While the described division of students in A-requesters and B-requesters aimed at answering the second research question on identity-neutrality, the different nature of request 1 and 2 aimed at testing the third research question, namely whether potentially controversial information is handled differently than uncontroversial information. In that connection, it is assumed that information concerning the wage level etc. of the highest-ranking civil servant of the administration in many cases will be seen as inconvenient to hand out to the public and perhaps cause anxiety among the political and administrative top management, as they might fear the issue getting bad press.

As already mentioned, the data set covers 73 municipalities (74.5 pct. of all municipalities) receiving two requests each, e.g. a total amount of 146 applications for access to information. The first applications were send 10. April 
2018, and the experiment was officially closed $1^{\text {st }}$ of June 2018. At that time, only one of the applications has been totally ignored by the municipality, and the applicant does - even though a reminder has been send - not have a decision or even an answer. This leaves us with a data set of 145 actual answers about access to information.

Shifting focus to the results on a more general level, especially three conclusions manifests itself from the data set:

First, generally seen, the municipalities handled the applications rather exemplary, as most applicants received the requested information without difficulties and within the set deadlines.

Table 1: Number of days for the response to the request. $\mathrm{N}=137$.

$\begin{array}{ccccccc} & \mathbf{0 - 1} \text { days } & \mathbf{2 - 7} \text { days } & \mathbf{8 - 1 3} \text { days } & \begin{array}{c}\mathbf{1 4} \text { days or } \\ \text { more }\end{array} & \text { Total } & \begin{array}{c}\text { Average } \\ \text { response time }\end{array} \\ \text { Answers } & 36 & 65 & 24 & 12 & 137 & 5.8 \text { days } \\ \text { In pct. } & 26.3 \% & 47.4 \% & 17.5 \% & 8.8 \% & 100 \% & -\end{array}$

Thus, as table 1 shows, 73.7 pct. of the applicants received an answer within 7 days, that is, within the standard time limit stated in the law. After 14 days, 91.2 pct. of the applicants have received a decision on the request for access to information. It is noteworthy to bear in mind, that these decisions with only very few exemptions granted the applicant access to the requested information. Moreover, the applicants were generally treated politely and respectfully and in relevant instances guided where to find additional information. Based on these results, the implementation of access to information regulation appears successful, at any rate in the municipalities when it comes to simple access to information applications.

Secondly, a crucial result from the analyzed data is that no differential treatment of applicants based on their status and qualifications can be observed.

Table 2: Number of days for the response to the request compared between qualified and non-qualified applicants.

\begin{tabular}{|c|c|c|c|c|c|c|}
\hline & $0-1$ days & 2-7 days & 8-13 days & $\begin{array}{c}14 \text { days or } \\
\text { more }\end{array}$ & Total & $\begin{array}{c}\text { Average } \\
\text { response time }\end{array}$ \\
\hline Qualified & 20 & 30 & 11 & 5 & 66 & 5.7 days \\
\hline In pct. & $30.3 \%$ & $45.5 \%$ & $16.7 \%$ & $7.6 \%$ & $100 \%$ & - \\
\hline Non-qualified & 16 & 35 & 13 & 7 & 71 & 5.9 days \\
\hline In pct. & $22.5 \%$ & $49.3 \%$ & $18.3 \%$ & $9.9 \%$ & $100 \%$ & - \\
\hline
\end{tabular}

Thus, there is only a slight difference in the response time for requesters $A$ compared to requesters $B$, as the average response time for the non-qualified 
applicants is 5.9 days, while the average response time for the more qualified applicants is 5.7 days, see table 2 . This is not a statistically significant difference; consequently, we cannot from this data set conclude that applicants with a certain status are consistently treated better.

However, third, but not least, we can observe a significantly higher processing time in the requests for potential controversial information than for less controversial cases. Table 3 illustrates this result:

Table 3: Number of days for the response to the request compared between nursing home and wage level.

\begin{tabular}{|ccccccc|}
\hline & $\begin{array}{c}\mathbf{0 - 1} \\
\text { days }\end{array}$ & $\begin{array}{c}\mathbf{2 - 7} \\
\text { days }\end{array}$ & $\begin{array}{c}\mathbf{8 - 1 3} \\
\text { days }\end{array}$ & $\begin{array}{c}\text { 14 days } \\
\text { or more }\end{array}$ & $\begin{array}{c}\text { Total } \\
\begin{array}{c}\text { Average } \\
\text { response } \\
\text { time }\end{array}\end{array}$ \\
\hline Nursing home & 22 & 31 & 9 & 6 & 68 & 4.8 days \\
\hline In pct. & $32.4 \%$ & $45.6 \%$ & $13.2 \%$ & $8.8 \%$ & $100 \%$ & - \\
\hline Wage level & 14 & 34 & 15 & 6 & 69 & 6.9 days \\
\hline In pct. & $20.3 \%$ & $49.3 \%$ & $21.7 \%$ & $8.7 \%$ & $100 \%$ & - \\
\hline
\end{tabular}

Thus, the average response rate for requests for access to municipal inspection reports on nursing homes is 4.75 days, while the average response time for access to the wage level of the top civil servant of the administration is 6.86 days. Moreover, decisions in 22.1 pct. of the cases concerning nursing homes exceeded the standard time limit on 7 days, while this was the case in 30.4 pct. of the cases concerning wage levels. However, the differences between the intervals of response time are not significant (ChiSquare, $p=0.333$ ), see table 3 .

An unexpected, yet interesting, finding of the study relates to the question of communication form. Notwithstanding the well-established requirement to be applicant blind, Denmark has not provided special systems ensuring anonymity when applying for information and documents. In that connection, the field experiment shows an interesting and potentially problematic development as some municipalities have established a new procedure for citizen requests of any kind. These municipalities requires routinely citizens to use the so called "sikker e-post" (secure e-mail), which is a digital solution for protecting personal information send by emails.

However, this digitalized communication form implies use of an official website (borger.dk) which is a digital self-service portal implying the use of a digital signature (NemID). NemID is an essential part of the Danish vision of a highly digitalized society including the public sector, but login and use presupposes entering one's personal identification number and combine it with a code from a personal code card. Thus, this digital arrangement is a rather demanding process (more demanding than just sending an e-mail), and furthermore, the attending case officer gets precise knowledge of the identity 
of the applicant via the personal identification number. On that background, prescribed use of this communication form when applying for access to information in public administration files may result in some citizens refraining from seeking access. Moreover, the official identification via the personal identification number may counteract the principle of applicant blindness as the civil servant handling the request may get access to other cases or incidents where the specific applicant has had contact with the authorities.

\section{Discussion}

The experiment can be seen as a pilot project characterized by trial-and-error in designing empirical based studies of access to information regulation, consequently, this affects the conclusions to be drawn. Thus, the field study contributes with perspectives and results that need to be taken in to account in future studies.

Thus, a basic methodological challenge is how to avoid that the public authorities got the suspicion of participating in a research experiment rather that handling an ordinary request for access to information. This was an almost unsolvable dilemma, as we at the same time strived to send identical emails to all municipalities in order to ensure comparability. In retrospect, it was a fault that the same person sent two rather different requests to the authorities within a rather short timeframe, as this could arouse suspicion.

Undoubtedly, these challenges need to be more thoroughly dealt with in future research designs in order to avoid the risk of biased and unreliable results because authorities are expected to behave better when they believe to be tested or inspected. Even though traces of such a suspicion could not be observed from the municipality's part, and even though the risk of arousing suspicion was reduced because the two requests was handled by two very different divisions of the municipality, the social desirability risk can't be excluded in the current study.

Even with these reservations, the study still seems to substantiate interesting assumptions. Hence, even though the principle of access to information has been under pressure in Denmark recent years, the preliminary results from this field experiment indicate that there is no cause for serious concern with regard to simple case processing in the municipalities. Generally seen, the applications were processed without difficulties and in most cases within reasonable time.

Moreover, there is no indication of systematically better treatment of and approach to applicants who officially present themselves as students of public administration and through that having a qualified background and professional interest in the requested information. Other potentially interesting grounds for differential treatment is yet to be analyzed.

However, the equal treatment does not manifest itself in relation to the nature of the specific information seeking access to. Thus, a more reluctant and 
sometimes delayed processing of applications asking for wage levels of leading civil servants was observed; information which easily can cause debate and controversies in the media. This result is interesting, though not surprising, and asks for further consideration and analysis in future studies.

This pilot-study, however, need to be supplemented with further research before solid conclusions on these issues can be drawn.

A supplementary interesting observation is the fact that the offensive Danish digitalization strategy in the public sector combined with a growing attention on privacy protection risk at hindering an easy and informal contact between the citizens and the public administration. This has also consequences for access to information and the principle of applicant-blindness, as some applicants possibly refrain from seeking access if it is too complicated or if they do not wish to be registered or recognized by 'the system'.

\section{Concluding remarks}

The results of the study showed, rather surprisingly, a fine implementation of the principles of easy access to information in Danish local authorities, as applications were processed without difficulties and in most cases within reasonable time. Besides, requesters were not treated systematically better, even though they appeared to be more qualified and stated a reason for applying for access. Certainly, requests for sensitive political information were handled more slowly than requests for non-controversial information, but the difference in case work time was not remarkably high.

As a final point, some concluding remarks on the question of student involvement. As indicated earlier, there were several good reasons for engagement of students in the research processes.

Firstly, it is worth mentioning the special history and characteristic of Roskilde University where the research initiative took place. Roskilde University was originally established in 1972 in the wake of the student uprisings of the 1960 's in order to challenge academic traditions and to experiment with new ways to create and acquire knowledge. Wanting a different approach to education and science, Roskilde University implemented new ideas in teaching and research. Most of these ideas remain central to the way that the university functions today. Thus, Roskilde University is known for its strong emphasis on group work and interdisciplinary teaching. Overall, Roskilde University continues to be the alternative university choice for students who want to have a greater say in how their time at the university is spent.

On that background, it seems obvious to involve students in research processes in order to increase their commitment to their education and the courses, strengthen the learning situation and creating synergy between the researcher and the students.

Secondly, the activities of the students implied real applications to and communication with administrative authorities in order to receive actual infor- 
mation on public matters. These activities will assumingly provide a better understanding of public administration and how the legal principles of administrative law is applied in practice.

Last, but not least, the field experiment would not have been possible without the help of my students. Collecting large amounts of data often requires a lot of manpower, which can be hard to provide for busy university professors and research staff. Hence, student involvement can often turn into a winwin situation; an initiative that benefits both parties. 


\section{References}

Access to Public Administration Files Act (2013) (Lov nr. 606 af 12. Juni 2013 om offentlighed i forvaltningen). At <https://www.retsinformation.dk/Forms/ R0710.aspx?id=152299>, accessed 27 May 2019.

Ahsan, M. (2014). Offentlighedsloven med kommentarer. København: Jurist- og $\varnothing$ konomforbundets Forlag.

Andersen, J. (2013). Offentlighed i forvaltningen. København: Jurist- og $\varnothing$ konomforbundets Forlag.

Berliner, D. (2014). The Political Origins of Transparency. The Journal of Politics, 76(2), pp. 479-491.

Bønsing, S. (2013). Almindelig forvaltningsret. 3. edition. København: Jurist- og $\varnothing$ konomforbundets Forlag.

Cuillier, D. (2010). Honey vs. Vinegar: Testing compliance-gaining theories in the context of freedom of information laws. Communication Law and Policy, 15, pp. 203-229.

Dragos, D.C, Kovač, P. and Marseille, A.T. (2019). The Laws of Transparency in Action - A European Perspective. Palgrave Macmillan.

Escaleres, M., Lin, S and Register, C. (2010). Freedom of information acts and public sector corruption. Public Choice, 145, pp. 435-460.

Grimmelikhuijsen, S. (2013). The Effect of Transparency on Trust in Government: A Cross-National Comparative Experiment. Public administration review, 73(4), pp. 575-586.

Helsingin Sanomat (2010). At <https://www.hs.fi/sunnuntai/art-2000004776771. html>, accessed 27 May 2019.

Hood, C. and Heald, D. (eds.) (2006). Transparency: the Key to Better Governance? Series: Proceedings of the British Academy. Oxford University Press for The British Academy.

Information (2015). At <https://www.information.dk/indland/2015/12/ ministerier-bruger-flittigt-kontroversiel-moerklaegningsbestemmelse>, accessed 27 May 2019.

Journalisten (2009). Volume 3. At <https://journalisten.dk/bladnummer/2009/ 2009-03>, accessed 27 May 2019.

Justitsministeriet (2017). Redegørelse om offentlighedsloven (Review on the Access to Information Act).

Jørgensen, O. (2014). Access to Information in the Nordic Countries. Göteborg: Nordicom.

Knudsen, T. (2003). Offentlighed i det offentlige - om historiens magt. Magtudredningen: Aarhus Universitetsforlag.

Koch, P.B, Gottrup, R. and Gøtze, M. (2018). Transparency on a bumpy road - Denmark. In D. Dragos, P. Kovač and A.T. Marseille, eds., The Laws on Transparency in Action - A European Perspective. Palgrave Macmillan, pp. 563-595.

Koch, P.B and Gottrup, R. (2019). Reversible Transparency - A study of the new Danish Access to Information Act. European Public Law, 25(2) (forthcoming).

Meijer, A.J. (2012). Introduction to the special issue on government transparency. International Review of Administrative Sciences, 78(1), pp. 3-9.

Michener, G. and Rodriguez, K. (2015). Who wants to know? Assessing discrimination in transparency and freedom of information regimes. Paper 
from the Fourth Global Conference on Transparency Research, Lugano, Switzerland, June 4-6.

Ministry of Justice (2009). White paper no. 1510.

Lagunes, P. and Pocasangre, M.O. (2017). Dynamic Transparency: An Audit of Mexico's Freedom of Information Act. Inter-American Development Bank Working Paper Series No. 836.

Lewis, D. and Woods, A.B. (2012). The paradox of agency responsibility: A federal FOIA experiment. At <https://www.vanderbilt.edu/csdi/research/CSDI_ WP_06-2012.pdf>, accessed 27 May 2019.

Price, S. (2006.). The official Information Act: A Window on Government or Curtains Drawn? New Zealand Centre for Public Law Occasional Paper, pp. $1-52$.

Revsbech, K. (2014). Forvaltningsret. Sagsbehandling. 7. Edition. København: Jurist- og Økonomforbundets Forlag.

Vaughn, R.G. (2011). Transparency in the Administration of Laws: The Relationship Between Differing Justifications for Transparency and Differing Views of Administrative Law. American University International Law Review, 26(4), pp. 969-982.

Worthy, B., John, P. and Vannoni, M. (2017). Transparency at the Parish Pump: A field Experiment to Measure the Effectiveness of Freedom of Information Requests in England. Journal of Public Administration Research and Theory, 27(3), pp. 485-500. 